\title{
Analysis of approaches to determination of extent of erosive hazard of slope lands
}

\author{
P. Nazarok \\ NSC "Institute for soil science and agrochemistry research named after O.N. Sokolovsky»
}

The purpose. Comparison and analysis of approaches used to determine the levels of erosion dangers, based on the assignment of land to technological groups and with the aid of Mirtskulava Hydromechanical Erosion Model (HEM). Methods. Geoinformational, mathematical- and-statistical. Results. In soil protection rationing of anthropogenic load on the technological groups of lands is a common practice. In this case, the only criterion for the selection of such groups is the angle of the earth surface. At the moment, the valid State Standard for calculation of the potential losses of soil is the one with the help of HEM. This Standard takes into account the basic meteorological, geomorphological, hydrological and soil indices, that determine the amount of potential losses of soil, and makes it possible to make informed design decisions in soil conservation. Conclusions. The assignment of land to the technological group has the features of a quality procedure that does not allow reasonable planning of crop rotation and agrotechnical tools for erosion- safe use of land. The main problem that occurs while using the HEM is the accuracy of input arguments. Their incorrect input leads to a multiple increase (decrease) of predictive values. Therefore there is a need to create database of reliable values of arguments for the erosive event scenarios.

Key words: slope soils, hydromechanical model of erosion by T.E. Mirtshulavy, erosion-hazardous lands.

Introduction. At the stage of ecological and economic substantiation of crop rotation and land management during the development of a land management project for agrarian engineering, the land surveyor must establish the degree of their erosion hazard [10,11]. This indicator can be determined in two ways: on the basis of the angle of inclination of the surface of the site, followed by the establishment of its belonging to the technological group, or by means of a mathematical model of equations that describe the water erosion of the soil under the influence of a shower. The purpose of the work is to compare and analyze the approaches to erosion hazards of the land: based on the classification of the land to the technological group and using the GME (hydromechanical model of erosion). The tasks of the study included: verification of GME at a testing ground located in the forest-steppe part of the Kharkiv region; calculation and statistical analysis of potential soil losses for technological groups; the study of the effect of changes in the values of the arguments of the equation on the predicted values of potential soil losses and erosion-safe lengths of the land.

Objects, methods and conditions of research. The object of the study was the selection of agricultural land "Colossus 2000" (Fig. 1, a) within the village councils of Rogan and Zelenyi Kolodyaz (Kharkiv and Chuguevsky districts of the Kharkiv region). DSTU foresees the use of the predictive model of soil losses due to water erosion under the influence of a shower of GME $[2,7,8]$.

Establishing the land belonging to one or another technological group was carried out according to such an algorithm: the construction of a digital model of relief on the basis of a topographic map (scale 1:10 000, horizontally conducted through $1 \mathrm{~m}$ ) and the derivative from it - the model of steepness of the slopes; calculation of frequency distribution of the values of angles of inclination for individual lands in groups - 0 - 1 - (la), 1-3 (Ib), $3-5^{\circ}$ (II b) [10,11]; the establishment of a technological group based on the ratio of the values of the particle shares of the above groups for the site [3]. To study the change in the value of potential soil losses and erosion-safe lengths of land (y) as a result of changing the value of one of the arguments of the GME (xk) with a constant value of the others, the partial elasticity index was determined. Under the elasticity of the function, it is understood how much the value of the function increases if the argument grows by $1 \%$.

The range and constant values of the arguments were as follows: slope length - $100-1000 \mathrm{~m}(400 \mathrm{~m})$; angle of inclination $-1-7^{\circ}\left(2^{\circ}\right)$; flow rate - 0,1-0,5 (0,25); coefficient of collapse - 1 - 3 (2); diameter of aggregates - 0,5-1,5 mm (1 mm); Duration of the shower - $10-60 \mathrm{~min}(35 \mathrm{~min})$; the intensity of the shower $-0,6-2,4 \mathrm{~mm} / \mathrm{min}(2 \mathrm{~mm} / \mathrm{min})$. To form the same ranges of arguments, their normalization was carried out for a range of $0-1$. To calculate the erosion-safe slope lengths, the potential losses at the level of $2.5 \mathrm{t} /$ ha were taken into account. 
Results and discussion. Verification of GME was carried out using the method of flushing in accordance with the results of measurements of aquifers [1]. The experiment was carried out as follows: across the slope on 15 counting sites measuring $84 \times 3 \mathrm{~m}$, the morphometric parameters of the marshs were measured and the soil losses in $\mathrm{t} / \mathrm{ha}$ for each plot were determined. The average value of loss of soil on the slope was $0.36 \mathrm{t} / \mathrm{ha}$. Input values for the forecast model were: bps $-1.25 \mathrm{~g} / \mathrm{cm} 3 ; \mathrm{d}-1,76 \mathrm{~mm} ; \delta-0.1$; I - $0.7 \mathrm{~mm} / \mathrm{min} ; \mathrm{M} 1-2$; T - $30 \mathrm{~min} ; \mathrm{ps}-2.6 \mathrm{~g} / \mathrm{cm} 3 ; \mathrm{P}-40 \%$ (arguments were based on field observations for density of soil structure, average size of aggregates, shower parameters and reference data for other indicators $[4,6,12])$. The slope parameters (length and angle of inclination of the surface) are based on the vector structural digital terrain model [5]. The simulation results are shown in Fig. 1. It can be stated that the used model with high probability predicts the loss of soil due to the shower.

To establish the degree of erosion hazard for the studied agroforesting lands, 2 approaches mentioned above are used. The following values of the GME arguments were taken into account when calculating the potential soil fault due to the rain of $10 \%$ : bps $-1.25 \mathrm{~g} / \mathrm{cm} 3 ; \mathrm{d}-1,0 \mathrm{~mm} ; \delta-0.3 ; \mathrm{I}-2,0 \mathrm{~mm} / \mathrm{min} ; \mathrm{M} 1-2.0$; T - $35 \mathrm{~min}$; ps - $2.6 \mathrm{~g} / \mathrm{cm} 3 ; \mathrm{P}-40 \%$.

The above loss of soil is calculated for black steam conditions. In order to objectively account for losses, the factor of water-erosion hazard of crop rotation was taken into account - $C$ (the value for field and soil protection crop rotation in the Kharkiv region is respectively 0.62 and 0.52 [9]) and the factor of soil protection measures is $P$ (value for cultivation across the slope is 0.75 [16]).

The results of determining the values of potential soil losses due to rainfall for technological groups indicate that the method of taking into account the inclination of the surface of the land can not ensure the conservation of the soil cover of the studied agro-landscape. When the permissible norm of soil losses for chernozems is $2 \mathrm{t} /$ ha [13], the calculated mean values exceed this value for all technological groups. The main thing to pay attention to is the scale of the potential losses and the various excess of the average values above the allowable rate of soil losses. That is, belonging to a technological group does not allow for a well-grounded erosion-safe crop rotation. The main reasons are different intervals of the angles of inclination for technological groups, their nonlinear influence and the ignoring of the slope lengths [15].

GME takes into account the basic arguments that influence the potential loss of soil due to the shower: hydrometeorological (intensity and duration of the shower); geomorphological (length and angle of inclination of the slope); soil (average size and bending of aggregates, density of the structure of the soil); integral hydrological parameters (runoff coefficient and coefficient taking into account the surface runoff concentration in the current grid, which is defined as the coefficient of collapse [8]). The above-mentioned indicators are not strictly interconnected or unconnected with the angle of inclination of the slope, and the calculated values of potential soil losses for technological groups may be completely different for the second territory. With excess of the values of potential soil losses for technological groups above the permissible norm, there may be another assumption - the inaccuracy of the predicted model, one of the reasons for which is incorrect input of the values of arguments. To show how the change of arguments affects predictive values, the GME equation is investigated using the parameter of partial elasticity of the function (Fig. $4, a)$. Significant influence on the value of potential soil losses has the coefficient of collapse, the duration of the shower and the angle of inclination of the slope. Accordingly, the elasticity of the function is $1.5 ; 1.0$ and 0.8. For the length of the slope, runoff coefficient and rainfall intensity, the elasticity of the function is 0.6. Extremely low elasticity of the function relative to the change in average diameter (roughness coefficient) 0.06 . The above form a series of arguments for the impact on potential soil losses under the influence of a shower.

To substantiate the erosion-safe lengths for technological groups of the earth, the partial elasticity of the function that determines it is investigated. Significant influence on the erosion-safe length has the coefficient of defect, the duration of the shower and the angle of inclination of the slope, respectively - 2,$3 ;-1.4$ and 1.3. For the intensity of the shower and the runoff factor, the value of the elasticity of the function is -1 . For a more practical application, let's give a graph of the multiplicity of the growth of a function with multiple growth of an argument for a known value of its elasticity.

For example, when changing the value of the coefficient of collapse from 1 to 2 or 3 , the value of potential losses will increase by 3 or 5 times, and the value of the erosion-safe length will respectively decrease by 5 or 13 times. That is, the effect of the values of the arguments on the predictive values is significant.

From the above calculations it can be concluded that it is necessary to form the basis of these values of arguments for scenarios of an erosion event, in particular for runoff and cumulative coefficients. For the hydrologically correct introduction of the angle of inclination and the length of the slope, one must take into account the longitudinal and transverse curvature of the slope. In the first approximation, coefficients for longitudinal profiles (straight -1 , convex $-1,25-1,5$, concave $-0,5-0,75$ ) and for cross - sections 
(transverse straight -1 , transversally convex - 0,8 , transversally-concave - 1,2). It would be correct to take into account the capacity of water streams instead of the length of the slopes to use the ratio of catchment areas to the width of the locking sections.

\section{Conclusions}

The attribution of the land to the technological group has signs of a qualitative procedure, which does not allow for the justified crop rotation and agrotechnical means for erosion-safe use of the land. The GME takes into account basic hydrometeorological, geomorphological, hydrological and soil indicators that determine the magnitude of potential soil losses and allows for the adoption of sound soil conservation design solutions. The main problem when using GME is the accuracy of the input arguments. The inadequacy of their input causes a multiple increase (decrease) of predicted values. Therefore, there is a need to create a database of reliable arguments values for scenarios of an erosive event.

\section{Bibliography}

1. Bulyhin S.Yu. Otsinka heohrafichnoho seredovyshcha ta optymizatsiya zemlekorystuvannya/S.Yu. Bulyhin, Yu.V. Dumin, M.V. Kutsenko. - Kh.: TOV «Svitlo zi skhodu», 2002. - $168 \mathrm{~s}$.

2. DSTU 7904:2015 Yakist' gruntu. Vyznachennya potentsiynoyi zahrozy eroziyi pid vplyvom doshchiv.3. Евдокимова Т.И. Почвенная съемка/Т.И. Евдокимова. - М.: Изд-во МГУ, 1987. - 271 с.

4. Instrukciya po opredeleniyu raschetnyh gidrologicheskih harakteristik pri proektirovanii protivoehrozionnyh meropriyatij na Evropejskoj territorii SSSR. — L.: Gidrometeoizdat, 1979. — $62 \mathrm{~s}$.

5. Kutsenko M.V. Heosystemni osnovy rehulyuvannya eroziyno-akumulyatyvnykh protsesiv: heomorfosystemnyy aspekt/M.V. Kutsenko. - Kh.: KP «Mis'ka drukarnya», 2012. - $320 \mathrm{~s}$.

6. Metodicheskie rekomendacii po uchetu poverhnostnogo stoka i smyva pochv pri izuchenii vodnoj ehrozii. — L.: Gidrometeoizdat, 1975. - 88 s.

7. Mirckhulava C.E. Inzhenernye metody rascheta i prognoza vodnoj ehrozii/C.E. Mirckhulava. - M.: Kolos, 1970. - $240 \mathrm{~s}$.

8. Mirckhulava C.E. Vodnaya ehroziya pochv/C.E. Mirckhulava. - Tbilisi: Mecniereba, 2000. - $420 \mathrm{~s}$.

9. Morgun F.T. Pochvozashchitnoe zemledelie/F.T. Morgun, N.K. SHikula, A.G. Tarariko. - K.: Urozhaj, 1988. $-256 \mathrm{~s}$.

10. Nakaz 02.10.2013 \# 395 «Pro zatverdzhennya metodychnykh rekomendatsiy shchodo rozroblennya skhem zemleustroyu i tekhniko-ekonomichnykh obgruntuvan' vykorystannya ta okhorony zemel' administratyvno-terytorial'nykh odynyts'»//Zemlevporyad. visn. - 2013. — \# 10. - S. 46-51.

11. Nakaz 02.10.2013 \# 396 «Pro zatverdzhennya Metodychnykh rekomendatsiy shchodo rozroblennya proektiv zemleustroyu, shcho zabezpechuyut' ekoloho-ekonomichne obgruntuvannya sivozminy ta vporyadkuvannya uhid'»//Zemlevporyad. visn. - 2013. - \# 10. - S. 52-63.

12. Pochvy Ukrainy i povyshenie ih plodorodiya; pod red. N.I. Polupana. — K.: Urozhaj, 1988. — T. 2. — $296 \mathrm{~s}$.

13. Spravochnik po pochvozashchitnomu zemledeliyu; pod red. I.N. Bezruchko, L.YA. Mil'chevskoj. — K.: Urozhaj, 1990. - $280 \mathrm{~s}$.

14. Statistichnij byuleten' «Posivni ploshchi sil's'kogospodars'kih kul'tur pid urozhaj».

15. Surmach G.P. Rel'efoobrazovanie, formirovanie lesostepi, sovremennaya ehroziya i protivoehrozionnye meropriyatiya/G.P. Surmach. — Volgograd,

1992. $-174 \mathrm{~s}$.

16. Wall G.J. 2002. RUSLE-CAN - Équation universelle révisée des pertes de sol pour application au Canada. Manuel pour l'évaluation des pertes de sol causées par l'érosion hydrique au Canada/G.J. Wall, D.R. Coote, E.A. Pringle et al. — Direction générale de la recherche, Agriculture et Agroalimentaire Canada, No de la contribution AAC2244F, $117 \mathrm{p}$. 